\title{
EM BUSCA DA "VERDADE REAL": TORTURA E CONFISSÃO NO BRASIL ONTEM E HOJE*
}

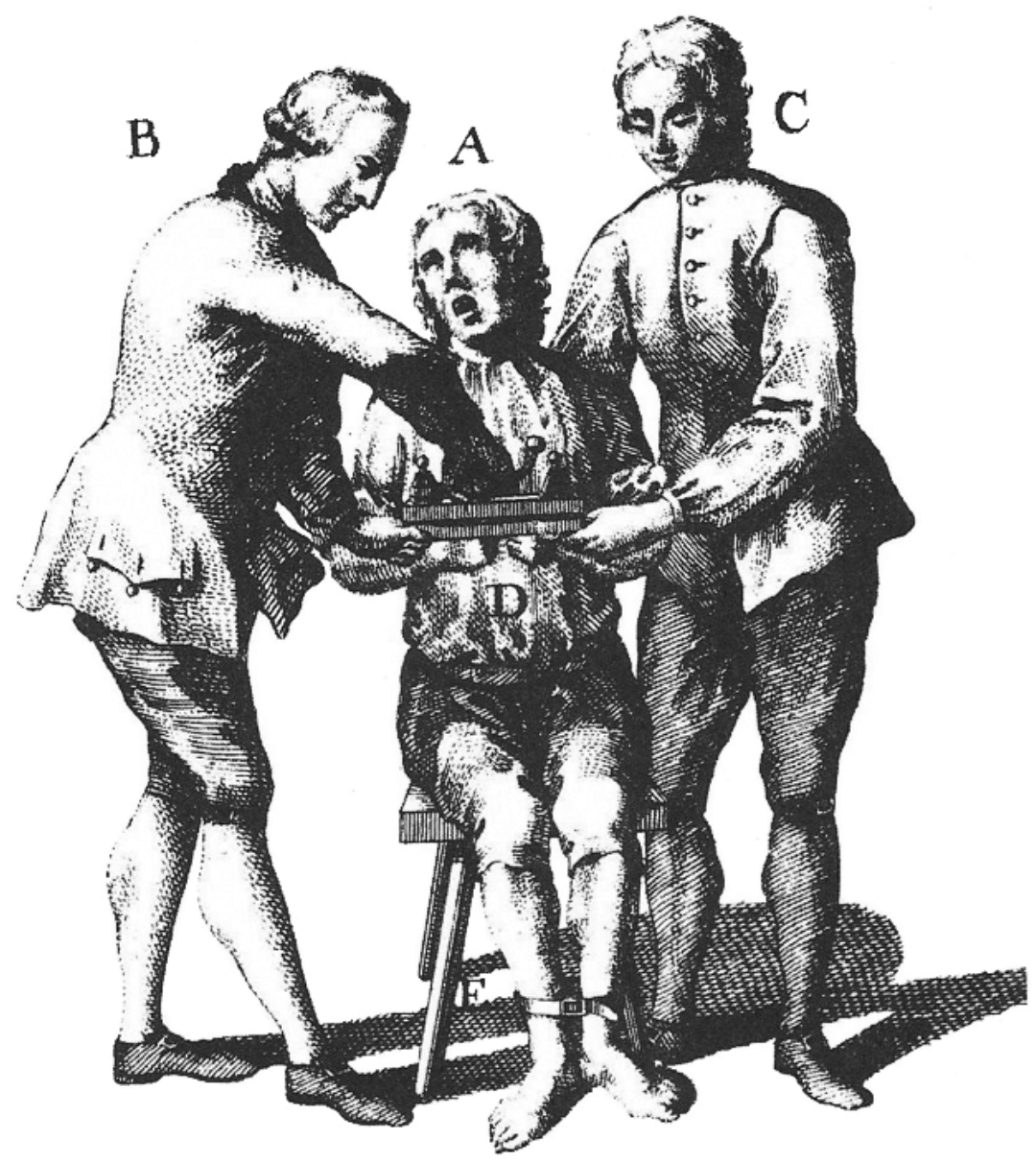

1. Gravura do século XVIII representando a aplicação do thumb-screw a um suspeito. 


\section{INTRODUÇÃo}

O viajante John Luccock, arguto observador da situação da capital do Brasil quando da chegada da família real, ilustra como eram, à época, as práticas de investigação policial no Rio de Janeiro. Comerciante inglês, Luccock relata um furto sofrido por ele e um amigo residente em sua casa, ocorrido no início de sua estadia de dez anos no país. Tendo as suas escrivaninhas furtadas e desesperados para reavê-las e resgatar os vários papéis e documentos comerciais que com elas haviam sido levados, ele e o amigo chegam, por dedução, a um suspeito: um mulato carpinteiro que havia realizado serviços na casa. ${ }^{1}$

Como àquela época acabara de ser criada a Intendência Geral de Polícia, dirigem-se, sem perda de tempo, ao "gabinete do Ministro da Polícia"2 munidos de evidências levantadas contra o carpinteiro, tidas por eles como bastante satisfatórias. O desdobramento da rápida iniciativa é frustrado, porém, com a resposta dada à solicitação que fazem de audiência com o intendente: "[...] sua excelência acha-se repousando e não poderia ser incomodada antes das cinco da tarde" (Luccock,1975: 91). Exasperados com o tempo ganho pelo suspeito, permitindo-lhe esconder ou dar fim aos produtos do furto, mas sem nada a fazer a não ser esperar, Luccock e o amigo conformam-se em retornar no horário agendado. À hora da esperada audiência, registra o viajante que ambos foram recebidos e tratados com muita amabilidade pelo ministro ${ }^{3}$ e que este, depois de ouvi-los, pediu-lhes para retornarem dali a oito dias.

Oito dias depois, na segunda audiência com o intendente, Luccock e seu companheiro são informados da prisão do carpinteiro na noite que se seguira ao furto. Ao relato da prisão, a autoridade acrescenta ainda que o carpinteiro, tendo sido torturado, não confessara o delito fazendo-se, portanto, necessária uma segunda tortura. Chocados e alarmados com a possibilidade de tal investida, os ingleses reagem alegando ser desnecessário aprofundar a investigação, bastando para eles a recuperação dos documentos. Comenta, ainda, Luccock, nessa passagem: "[o intendente] sorriu da nossa sensibilidade que, está visto, achou deslocada, convidando-nos a comparecer na semana seguinte" (Luccock, 1975: 92).

$\mathrm{Na}$ terceira e última audiência, os ingleses são informados de que o acusado finalmente reconheceu a autoria do crime e da queima e perda irremediável dos papéis e documentos. Luccock finaliza a sua narrativa dizendo ignorar o destino dado ao carpinteiro.

\section{DOIS MODELOS DE ADMINISTRAÇÃO DA JUSTIÇA}

John Luccock, assim como outros viajantes do século XIX, descreve e interpreta suas experiências vividas no Brasil, tomando por base os seus referenciais de origem (Leite, 1996). A descrição que faz da conduta que ele e seu amigo adotam 
para solucionar o furto ancora-se em uma concepção de administração da justiça apoiada em mecanismos de decisão que privilegiam modelos de bom senso adotados pelo homem comum. Estes são procedimentos fundados "naquilo que todo mundo sabe" para decidir sobre os fatos ou sobre como os fatos devem ser. Tal forma de administrar justiça alicerça-se em uma prática produzida pela troca de pontos de vistas sobre fatos a serem arbitrados por um tribunal. E é por isso que, ao proceder à reconstituição do que foi que aconteceu, só admite a confissão se essa for espontânea e não se provocada pelo interrogatório do réu. Trata-se de uma concepção, ao mesmo tempo, familiar ao leitor de seu país (em última instância, destinatário da descrição) e distanciada das práticas locais. E é com um olhar próprio aos viajantes, o da diferença, que Luccock distinguirá o modo de administrar a justiça no Brasil daquele de seu país de origem. De um lado, na maneira de conduzir a investigação, sem preocupação com o levantamento de indícios e, de outro, no uso da tortura para obtenção da confissão.

Vale lembrar que na Inglaterra, país de origem de Luccock, a tortura havia sido definitivamente abolida por lei editada ainda em 1640. E a razão pela qual tal prática, embora ali presente, sempre se mantivera marginal deve-se ao desenvolvimento de uma tradição legal, constituída ao longo de séculos, voltada para a manifestação da vontade da comunidade (Ribeiro, 2004) e não para o julgamento de uma verdade última (Langbein, 2006). ${ }^{4}$

A administração da justiça dos países da Europa continental, por sua vez, foi se ancorando, a partir do século XIII, em um modelo misto de direito romano, canônico e germânico, racionalmente construído e centrado na decisão de juízes. Seu bastião era um sistema de provas que permitisse alcançar a verdade que mais se aproximasse da verdade divina (Langbein, 2006). Valia-se, para tanto, de testemunhos oculares considerados idôneos ou da confissão do réu. Entretanto, dada a dificuldade de obtenção de testemunhos, o sistema centrava-se, de fato, na confissão. E nos casos em que esta não fosse conseguida espontaneamente, ou ainda, se a confissão não satisfizesse o interrogador (geralmente munido de informações anteriores), então empregava-se a tortura.

Trata-se, portanto, de uma prática controlada por juízes e regulada legalmente por meio de regras preestabelecidas que passou a ser utilizada em casos de crimes que resultavam em pena capital. ${ }^{5}$ Uma dessas regras previa o emprego da tortura para se obter a confissão somente se houvesse o registro de pelo menos um testemunho, vindo este a constituir, no cálculo estabelecido pelo sistema romano-canônico, uma meia-prova. ${ }^{6}$ Nesse sentido, confissão e tortura, ou a ameaça desta, formam partes relacionadas de um mesmo sistema. E no direito continental, encontram-se voltadas para a busca de uma verdade imanente. $^{7}$

Este sistema romano-canônico de provas baseado na tortura judicial foi perdendo força na Europa continental ainda no século XVII. E isto se deu menos em razão da comprovada ineficiência deste procedimento, ${ }^{8}$ do que de uma maior 
profissionalização e discricionariedade do judiciário (Langbein, 2006). Deveu-se, também e principalmente, ao desenvolvimento de novas formas de punição de caráter disciplinador, tais como a prisão e os trabalhos forçados (Foucault, 1988; Langbein, 2006). ${ }^{9}$ A tortura física para obtenção da confissão, utilizada em crimes de pena capital, foi sendo, na prática, restringida aos crimes cometidos contra o rei ou contra o Estado e não tardou a cair em desuso, antecipando a sua eliminação formal dos códigos penais europeus, a exemplo do Código de Instrução Criminal francês, que a aboliu em 1808.

Mas em países onde atuava o Tribunal do Santo Ofício, como era o caso de Portugal, a mudança ocorreu tardiamente. Se a tortura na jurisprudência eclesiástica foi reformada no último regimento da inquisição portuguesa, ainda no período final da administração pombalina, em 1774, esse mesmo regimento, entretanto, manteve os suplícios em casos de heresiarcas dogmáticos. O que veio, de fato, a ser proibido foi o segredo do processo e o anonimato das testemunhas denunciantes (Bethencourt, 2000). Apesar disto, o Tribunal da Inquisição, desde então enfraquecido em Portugal, somente foi extinto em 1821 com as revoluções liberais. Três anos depois, a tortura no Brasil foi abolida na Constituição Imperial outorgada por D. Pedro I, portanto pouco mais de uma década após o texto de Luccock. ${ }^{10}$

O Tribunal de Inquisição português era imbricado com a justiça secular de muitas maneiras. Esta não só lhe sucedia na aplicação das penas para certos tipos de crimes, como também adotava muitos dos seus procedimentos de investigação, essencialmente centrados na confissão e na tortura visando a sua obtenção (Lima, 1999; Bethencourt, 2000). Contudo, na segunda metade do século XVIII, a tortura legal para obtenção da confissão e o segredo da denúncia de crimes cuja pena era a condenação à morte, parecem já constituir exceções na justiça secular portuguesa.

É o que nos revelam vários documentos contidos no famoso Processo dos Távoras (Azevedo, 1921). Este foi constituído no início da administração de Pombal, em 1759, para julgar destacados integrantes de famílias da aristocracia portuguesa e alguns jesuítas, acusados da tentativa de assassinato do rei D. José I. Dentre os documentos do processo, consta uma representação feita ao Rei pela comissão de desembargadores julgadores solicitando autorização para o emprego da tortura e para desnaturalizar os réus. Além da representação, consta ainda um pedido para se admitir denúncias feitas em segredo. Ambas as práticas, tratadas no processo como excepcionalidade, foram, nessa ocasião, amplamente utilizadas, registradas e justificadas pelo teor e gravidade do crime. ${ }^{11}$

Mas, mesmo Portugal não ficou imune aos ventos das mudanças no que tange a administração da justiça. O Processo dos Távoras foi revisto durante o reinado de $D$. Maria I e os juízes da revisão repudiariam com veemência o uso da tortura (Alves, 2011). Uma outra indicação nessa direção é dada pela com paração do processo de 1759 com os autos da devassa, constituídos para acu- 


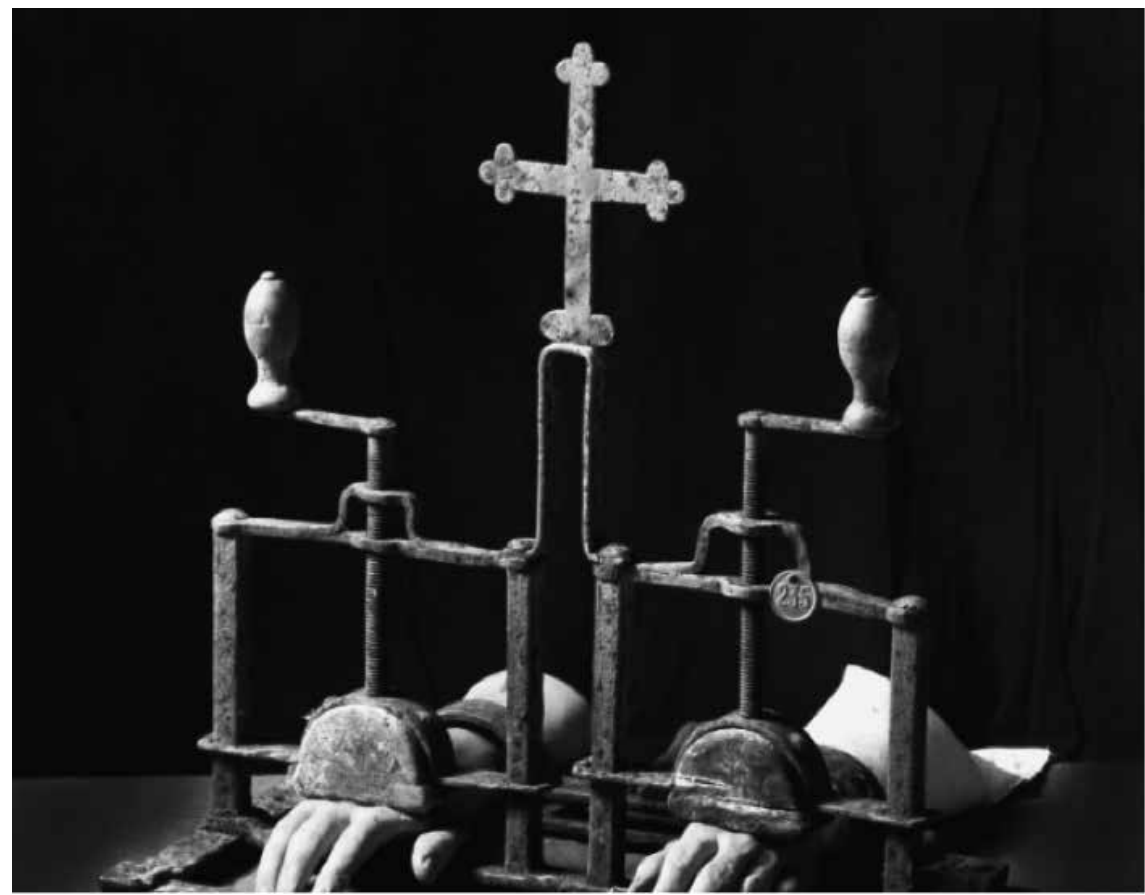

2. Esmagadores de mãos

sar os participantes da conjuração mineira ocorrida em 1789 , somente trinta anos depois. Na devassa da conjuração, nenhuma referência textual é feita ao emprego legal da tortura para a obtenção da confissão, tal como ocorreu no Processo dos Távoras. ${ }^{12}$

Contudo, seria necessário melhor conhecer o quanto a tortura era empregada para a obtenção da confissão de réus das camadas populares quando da investigação de eventos que, na prática, não redundavam em pena capital, ${ }^{13}$ como nos sugere, dentre outros, o caso do carpinteiro, narrado por Luccock. ${ }^{14}$

\section{A CRIAÇÃO DA INTENDÊNCIA DE POLÍCIA: CASTIGO, CONFISSÃO E TORTURA}

As mudanças, decorrentes das reformas do absolutismo esclarecido e da emergência de novas formas de controle, também se fizeram sentir no aparecimento de novas instituições. Foi o que ocorreu com a Intendência Geral de Polícia, criada em 1762 em Portugal com o propósito de atender ao novo desafio, colocado ao Estado, de civilizar e exercer o controle das populações urbanas. Com a vinda da família real, essa instituição foi transplantada para o Brasil, a exemplo do que ocorreu com outras instituições portuguesas que conservaram não apenas os seus nomes de origem, como também funcionários e vícios, sem consideração às especificidades locais e às dimensões do país (Varnhagen,1962: 221-223). 
No Brasil, a Intendência de Polícia acabou restringindo a sua esfera de controle, administração e repressão da população, à cidade do Rio de Janeiro. Por ocasião da criação da intendência local, quase metade da população da cidade era constituída de escravos negros. Outra boa parte integrava, em grande medida, aquilo que os funcionários coloniais, referindo-se à população livre e pobre do Brasil como um todo, chamaram de "ínfima plebe": vagabundos, desempregados e subempregados (Boxer, 2002: 211) e também uma espécie de classe média baixa (Silva, 2011). Ambas formadas de mestiços, mas também de brancos pobres e pretos livres. ${ }^{15}$

Cenas de violência e brutalidade contra os escravos eram comuns. Para espanto dos viajantes, essa população de escravos que perambulava pelas ruas ostentava inúmeros objetos de sevícia: correntes, troncos, pegas, algemas etc. (Shwarcz, 2011). A esta eram aplicados não apenas castigos físicos, visando o controle e a punição, mas também suplícios para a obtenção da confissão. Em princípio menos visíveis, tais suplícios apareciam na cena pública quando dirigidos a cativos. É o que relata Leithold, um prussiano que esteve no Brasil à mesma época de Luccock, ao narrar a tortura sofrida por um negro, que estivera a seu serviço, denominado Manuel. ${ }^{16}$

Conta o viajante que, depois de já estar há algum tempo prestando-lhe serviços, Manuel desapareceu. Três dias após o sumiço, Leithold é surpreendido quando "apareceram-me três policiais com o meu Manuel de mãos algemadas por um instrumento semelhante a uma fechadura de portas [...]". Em conversa com os policiais, o estrangeiro descobre tratar-se de um escravo fugido e desvela o propósito dos agentes da polícia de com ele confrontar a estória contada pelo escravo, bem como o de dar busca a uma carta de alforria falsa que estes alegavam estar escondida na casa. Ainda, segundo o estrangeiro: "Quiseram arrancar do pobre diabo uma confissão mediante tortura, apertando-lhe as mãos com a referida fechadura o que lhe fez dar gritos de dor [...]" (Leithold \& Rango,1966: 35).

A narrativa termina com o suposto documento de alforria não sendo encontrado e o escravo reconduzido ao seu antigo dono, um major de polícia, a quem Leithold endereça uma carta pedindo para que o castigo do fujão fosse aliviado o máximo possível.

A violência policial amplamente utilizada contra os escravos, à época da instalação da Intendência de Polícia (Holloway, 1997), não se restringia a estes, conforme atesta Luccock em sua narrativa sobre o furto atribuído ao carpinteiro mulato e livre. Apoiada na sociedade escravista e, a partir da criação da intendência, cada vez mais em sua própria autoridade, a polícia pouco considerou, nos casos em tela, a preferência dos reclamantes estrangeiros e os seus pedidos de indulgência. ${ }^{17}$ Mas, o curioso é que, no caso de Luccock, embora este repudiasse a tortura e torcesse para que ela não tivesse sido empregada contra o carpinteiro, a sua possível ocorrência não pareceu ter lhe causado um grande estranhamento. Ele já a conhecia. 


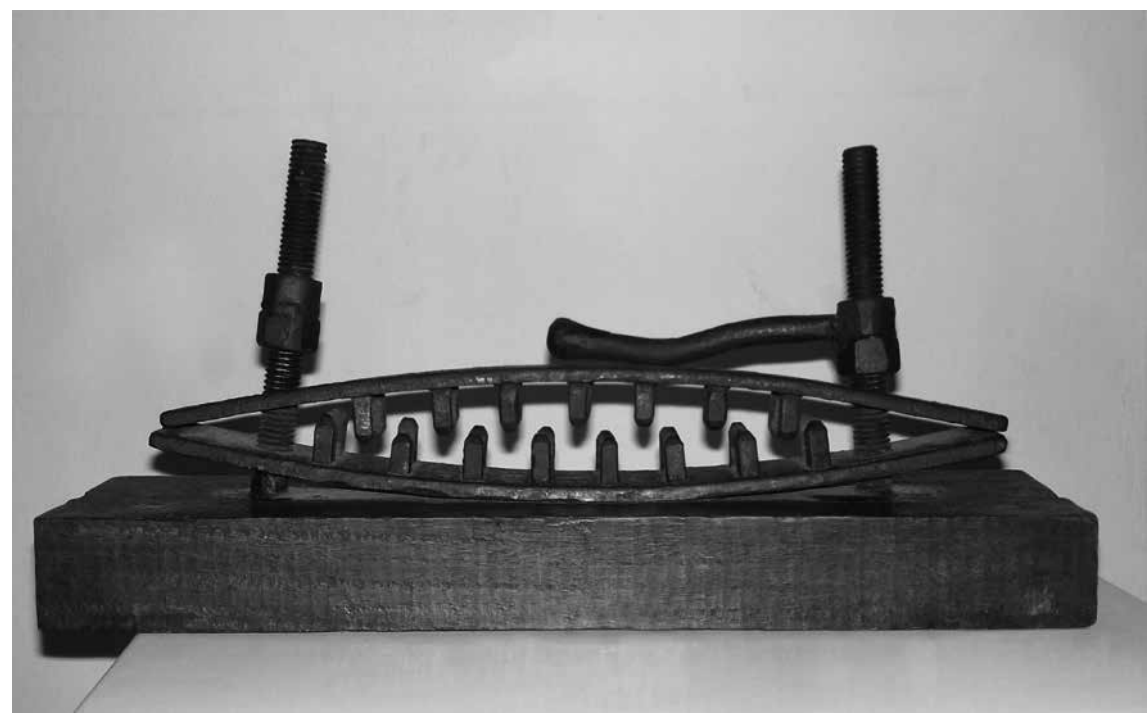

3. Réplica em madeira e ferro do esmaga-polegares.

Digo isto porque o autor não ofereceu maiores explicações aos leitores ingleses além da expressão "he had been thumb-screwed" utilizada para se referir à tortura feita ao carpinteiro. Tampouco fez referência ao thumb-screw, instrumento de tortura usado nos tribunais medievais, no tribunal de inquisição e também nos castigos aplicados aos escravos ainda em sua época, conforme descreve Leithold. Tal dispositivo, formado de duas placas de metal separadas por parafusos que provocam o esmagamento dos dedos ou dos polegares, vem a ser a tal "fechadura" descrita por Leithold. A praticidade deste instrumento era reconhecida por ser portátil e por provocar o máximo de agonia sem demandar muito esforço do torturador.

Por que então Luccock (diferentemente de Leithold) não se deu ao trabalho de fornecer aos seus leitores maiores esclarecimento sobre este instrumento? É possível que o não estranhamento se deva à existência e acúmulo de uma extensa literatura contrária à tortura produzida ou traduzida na Inglaterra, desde o final do século XVII, elaborada com base em narrativas de ex-presos perseguidos pela inquisição (Bethencourt, 2000). Ou, como aparece em Arthur Ramos, informada por relatos dos suplícios aplicados a escravos negros advindos das possessões inglesas e francesas, reputados por serem mais violentos do que aqueles empregados nas colônias espanholas e portuguesas (Ramos, 1942). Tal produção revela, de um lado, a existência de um público crítico e informado e, de outro, um conhecimento amplamente difundido na Inglaterra à época de Luccock, de certas práticas de tortura e dos instrumentos utilizados para aplicá-las. 


\section{PERMANÊNCIAS E MUDANÇAS}

Quase duzentos anos depois, a expressão usada por Luccok é retomada, em meados da década de 1980, pelo historiador americano Thomas Holloway, em seu livro sobre a polícia do Rio de Janeiro no século XIX, referindo-se a essa passagem do relato do viajante estrangeiro. Na versão original de Holloway, o termo é utilizado, como em Luccock, sem mais explicações. Já em sua versão do trecho "he had been thumb-screwed" para a língua portuguesa, o tradutor utilizou a expressão "aplicar anjinhos", novamente sem merecer nenhuma nota ao leitor.

Sobre este fato algumas hipóteses podem ser levantadas: a expressão não precisaria ser esclarecida ao leitor, também como em Luccock, porque daria nome e significado a uma prática ainda comum nas delegacias brasileiras, quase dois séculos depois? Ou teria o tradutor encontrado a expressão "anjinhos" na obra de Arthur Ramos que descreve, nomeia e classifica os diferentes tipos de castigos e suplícios infligidos aos negros escravos? ${ }^{18}$ Neste caso, a segunda hipótese anularia a primeira porque, para Arthur Ramos, com a abolição da escravidão, esses instrumentos de tortura caíram em desuso. Foram escondidos ou enterrados, assim como o interesse dos historiadores e sociólogos por eles (Ramos, 1942: 109).

Quem irá nos falar da aplicação de "anjinhos" é Francisco Viriato Corrêa, vulgo Japonês, um dos fundadores do Comando Vermelho, ${ }^{19}$ em entrevista dada no início dos anos 1990. À pergunta do entrevistador sobre se havia sido torturado, Japonês, referindo-se a sua prisão em 1971, responde (segundo o entrevistador, com os braços arrepiados pela lembrança): "Isso aqui eram os anjinhos, uns vergalhõezinhos que se colocavam entre os dedos. Tenho marcas até hoje...". E mostrando os dedos arremata: "são marcas inesquecíveis...". ${ }^{20}$

Assaltante de banco, Japonês fora enquadrado, durante o Regime Militar, na Lei de Segurança Nacional que não diferenciava, nesses casos, o preso comum do preso político e funcionava como artifício para não permitir o reconhecimento dos crimes de natureza ideológica. Essa e outras formas de tortura relatadas pelo assaltante foram também estendidas, à época, como se sabe, aos presos e militantes políticos.

Nessa ordem de ideias prevaleceria, então, a primeira hipótese. Qual seja, a de que essa prática era ainda comum. Se verdadeira, dela deriva concluir uma impressionante continuidade, no espaço de duzentos anos, dos mesmos métodos e instrumentos de tortura utilizados para arrancar a confissão. Ao buscar seguir as pistas deixadas pelo uso de um de seus instrumentos - "os anjinhos" -, estou sugerindo, até aqui, que a tortura para a obtenção da confissão permanece no Brasil, constituindo já uma tradição. Essa prática foi e tem sido reservada para arrancar a confissão de suspeitos de classes populares de cada época, expandindo-se para outras classes nos períodos de exceção. Entretanto, 
as camadas populares vêm constituindo, no passado e no presente, a clientela preferencial da polícia e da justiça, conforme atesta John Luccock, para o passado, no seguinte trecho referindo-se mais uma vez ao Brasil:

As leis eram tão imperfeitas ou então aplicadas com tamanha imperfeição, que as pessoas brancas pareciam ter-se aos poucos convencido de se acharem acima delas (isto é acima das leis). Creio que mui poucos dessa classe tivessem recentemente sido presos, por crimes que não fossem contra o Estado, os mulatos gozavam das mesmas isenções, à proporção que seu tom se aproximava do moreno ou claro (Luccock,1975: 92).

Na tradição nativa de Luccock, as leis foram construídas no dia a dia das relações sociais, adquirindo, com o desenvolvimento do liberalismo ao longo do século XVIII, tradição de universalidade e, em consequência, ampla legitimidade. ${ }^{21}$ Outra tradição constituiu-se no Brasil-Colônia, onde as leis foram impostas pela metrópole, embora, como observado por Luccock, fossem, naquele momento, frequentemente pouco aplicadas e pouco seguidas. Posteriormente, com o país independente, passaram a ser elaboradas e aplicadas por bacharéis que se valiam de valores e teorias transplantados de outras formações e contextos. Tais valores, ancorados cada vez mais na crença na autonomia e liberdade do indivíduo para perseguir os seus próprios interesses, entravam em conflito, evidentemente, com as condições locais de dependência de todos e de subordinação e submissão da maioria aos interesses da ordem escravocrata. Assim, além de não terem por referência as práticas locais, as leis não foram constituídas com base na crença do valor de sua universalização, como argutamente observou Luccock. Como se sabe, disto decorreu características que nos moldam até hoje: um estado legiferante, que busca controlar pela lei a tudo e a todos e um enorme fosso entre leis e práticas, com o descompasso entre leis moderníssimas, porém, aplicadas desigualmente para desiguais. Este tem sido um tema amplamente explorado na literatura e, no que diz respeito à administração da Justiça, especialmente por Roberto Kant de Lima (2004, 2008).

Enfatizar permanências não implica, contudo, considerar as sociedades estáticas. Na Inglaterra, por exemplo, no período logo posterior a Luccock deu-se uma mudança importante com o surgimento da força policial moderna. Com ela, o foco da investigação criminal deslocou-se do processo judicial para a investigação policial e ao adotar o interrogatório do réu na polícia, esse sistema não ficou imune ao uso da violência física na sua realização (Langbein, 2006). Apesar de, ainda em 1912, terem sido estabelecidas regras judiciais para a detenção e interrogatório do suspeito pela polícia, estas passaram a ser recorrentemente violadas. A justificativa era a de que práticas não autorizadas seriam necessárias para se deter o crime e de que o regime de direito, imposto ao trabalho policial, tornaria este último tarefa impossível (Neocleous, 2000: 182). Na atualidade o debate em torno da contenção do poder da polícia centra-se no controle democrático desta instituição. 
Já no Brasil, esse mesmo deslocamento da investigação, fez com que a polícia reunisse duas prerrogativas: a de investigar, que é uma função administrativa, e a de formar a culpa, que é uma função judiciária. Nessa mesma época, em 1871, foi criado o Inquérito Policial, um documento escrito, obrigatório e de fé pública, isto é, com veracidade atestada pelo Estado, cujo propósito é reunir os resultados da investigação, realizando a sua transposição para a lógica e linguagem jurídica. Como resultado dessas mudanças coube à polícia muito mais do que simplesmente levantar indícios de provas para auxiliar a decisão do promotor de processar (Misse, 2010; Vargas \& Nascimento, 2010). Prática já arraigada anteriormente e que encontrou terreno fértil, particularmente no tribunal de inquisição, o emprego da confissão em busca da verdade real, ${ }^{22}$ consolidou-se como tradição e como principal ferramenta de investigação da polícia (Lima, 1989, 2008).

Considerar essas permanências tampouco nos deixa ignorar as mudanças provocadas pelos movimentos sociais, em particular aqueles de repúdio à tortura. Na década de 1980 a criminalização da tortura ganhou importância com a convenção da ONU contra a tortura e outros tratamentos ou penas cruéis, desumanos e degradantes, determinando que estados signatários adotassem a criminalização em sua legislação. No Brasil, o movimento constituinte logrou criminalizar a tortura na Constituição de 1988, tornando a sua prática crime inafiançável e insuscetível de indulto ou anistia. A sua criminalização em lei específica foi instituída em 1997. Além da criminalização, outro movimento importante tem sido o da educação dos operadores da segurança pública em direitos humanos. Contudo, essas mudanças nas leis e também nas orientações governamentais continuam distanciando-se das práticas e são de pouco impacto na medida em que quase não trazem custos efetivos para os que violam garantias de direitos e liberdades civis.

O problema é que a prática de tortura para obtenção da confissão é ainda vista, não apenas por policiais, mas também por uma importante parcela da população, como método de trabalho justificado para o controle do crime. ${ }^{23}$ À dificuldade de se punir a tortura e ao apoio social à prática, somam-se os padrões dos crimes violentos que não permitem facilmente a obtenção de testemunhos, a falta de qualificação da polícia em técnicas de investigação e a pressão para "mostrar serviço", este sendo medido, mais recentemente, com base em índice quantitativo de produção de inquéritos policiais (Vargas \& Nascimento, 2010). Se a confissão é uma prova hoje considerada de valor relativo pelo discurso jurídico, na prática policial ela continua sendo elemento central. E é na importância dada à confissão que se integra a tortura (Lima, 1994).

É sobre a centralidade da confissão na investigação policial e sobre a transformação da confissão em peça-chave nos relatos escritos que irão compor o inquérito policial que irei desenvolver, a seguir, a segunda parte do meu argumento. 


\section{TORTURA E CONFISSÃO NA CONSTITUIÇÃO DA FATICIDADE JURÍDICA}

A constituição da faticidade jurídica tem sido, ao longo dos anos, o meu principal interesse de estudo (Vargas, 2000; 2004; 2007). Tenho centrado minha investigação no processo de construção social e institucional do crime (desde a etapa policial até a judiciária) e refletido sobre a importância dos relatos escritos na constituição do fato jurídico. Em meu primeiro estudo, escolhi trabalhar com os crimes sexuais porque neles a faticidade aparece de maneira particular. Em geral, conta-se com poucas versões originais sobre o acontecimento: apenas a da vítima, e com menor frequência, sua versão e do agressor. Além disso, são muitas as dificuldades para a comprovação da materialidade, tendo em vista que, na maioria das vezes, os exames não são conclusivos.

O questionamento da própria existência do evento, enquanto crime, singulariza boa parte dos casos de crimes sexuais. Isso ocorre nas situações em que a vítima e o agressor se conhecem e resulta, na polícia, na produção de uma verdade negociada, reconhecida como dependente das versões apresentadas pelas partes. Um outro padrão de ocorrência é aquele que envolve desconhecidos acusados de agressões sexuais consideradas graves pela lesão ou pelo resultado que provocam. Nesses casos, a busca da verdade visa atingir a "verdade real" e volta-se para produção de provas (Vargas, 2000; 2004).

Ilustra este padrão uma tentativa de estupro ocorrida com uma jovem de quinze anos, cujo desenrolar acompanhei desde o registro da queixa até a sentença. A acusação recaiu sobre dois indivíduos. O rito de reconhecimento dos agressores não foi decisivo, tendo em vista que, como explicou a vítima, a luz e as circunstâncias não permitiram que ela os visse direito. Um dos acusados chegou algemado à delegacia e lá permaneceu até ser levado preso para outro distrito. E o outro, que compareceu escoltado por policiais e acompanhado de seu chefe no banco em que trabalhava, acabou sendo liberado para voltar no dia seguinte munido de provas. O rapaz do banco não foi indiciado. Já o que fora preso, de acordo com as policiais da delegacia pesquisada, ao ser levado para outro distrito, foi torturado e acabou confessando a tentativa de estupro. ${ }^{24}$ Posteriormente, foi interrogado e seu depoimento registrado no inquérito policial.

Narrativas de torturas, ocorridas em delegacias de polícia visando obter a confissão de supostos criminosos, são comuns e constituem os casos mais recorrentes desta prática hoje no Brasil. ${ }^{25}$ O perfil dos torturados, assim como no passado, é o das classes populares, concentrado, atualmente, em jovens vivendo em condições socioeconômicas precárias, de baixa escolaridade, pretos e pardos. ${ }^{26}$ Contudo não é fácil conhecer a magnitude destas práticas na atualidade, tendo em vista tratar-se de um evento de difícil visibilidade e registro. Dentre outros porque a maior perpetradora da tortura, a polícia judiciária, é também a principal responsável pela sua apuração, hoje tipificada no Código Penal como crime inafiançável (Jesus, 2009). No crime de tortura, assim como nos crimes 
sexuais, fica a palavra da vítima contra a do acusado que, neste caso, e isto faz toda a diferença, é agente do Estado.

Os primeiros estudos etnográficos que abordaram o emprego da tortura na polícia civil mostraram como ele é instrumental para o trabalho da investigação. A tortura permitiria aos policiais solucionarem crimes de forma mais econômica (Paixão et al., 1992), de tal maneira que, quando não fosse possível utilizá-la, muitos inquéritos policiais ficariam sem solução (Lima,1994). A ameaça de seu emprego funcionaria também como pressão para se negociar, de maneira ilegal, a não criminalização da ocorrência (Mingardi, 1992). Nessa negociação de "mercadorias políticas" os policiais valer-se-iam da autoridade que lhe é conferida pelo Estado para a satisfação de seus interesses privados (Misse, 1999). Assim, violência e corrupção não seriam desvios, mas atividades rotineiras do universo policial (Mingardi, 1992).

Para proceder à investigação, de maneira a descobrir criminosos potenciais e distingui-los de trabalhadores respeitadores da lei, a polícia decidiria com base em uma "ética", desenvolvida internamente, ancorada em um código cultural evolucionista (Lima, 1989: 75) ou em uma "lógica em uso" (estereótipos formulados organizacionalmente), que permitiria a "tradução da lei" em categorias morais (Paixão, 1982). São elas que orientariam as decisões sobre quem e em que situação seria conveniente ou não torturar. Disto resultaria a variação desta prática conforme tipos penais e a posição social do réu.

Foi dito que a tortura desenvolveu-se, como prática legal, em razão da importância dada à confissão para a produção da prova no sistema continental. Desfeita a sua áurea de legalidade, a tortura mantém-se atrelada à confissão, agora justificada pela sua instrumentalidade. Diante da dificuldade de se mensurar esta prática, qual seria então o peso da confissão nos procedimentos de investigação hoje no Brasil?

Recentemente, em pesquisa nacional realizada sobre o inquérito policial em cinco capitais brasileiras, ${ }^{27}$ observamos, para Belo Horizonte e com base em informações levantadas em processos de homicídios dolosos, que os indícios de "provas" eram obtidos essencialmente por meio de testemunhos e pela confissão do réu. ${ }^{28}$

Os dados etnográficos e as informações dos processos indicaram também ser rara a atividade investigativa que faça uso de meios mais modernos de investigação. Ao tratar os dados dos inquéritos bem-sucedidos, que se tornaram processos, identificamos um percentual muito baixo desses documentos com perícia de local do crime ou outros tipos de perícias tecno-científicas. Nessa mesma direção, observamos um baixo número de "diligências externas" realizadas no decorrer do processo investigativo, fato também revelador da falta de investigação (Vargas \& Nascimento, 2010).

Além da ênfase dada ao depoimento de testemunhas, em detrimento da coleta e análise de provas técnicas, o que mais nos chamou a atenção, nos 
processos analisados em que foi possível obter a informação, foi o alto percentual de homicidas confessos:

\begin{tabular}{l|c} 
Tipos de procedimentos & Média por Inquérito \\
\hline Perícias & 2,5 \\
\hline Diligências externas & 3,5 \\
\hline Depoimentos de testemunhas & 7,0
\end{tabular}

Tipos de procedimentos nos inquéritos de processos de homicídios dolosos BH/MG (1985-2003)

Fonte: TJMG/NESP-FJP/UFMG-CRISP.

Nos inquéritos analisados verificou-se que em $80 \%$ dos casos houve a confissão do suspeito. É aqui que aparece, com mais clareza, a prática policial de formar a culpa, que era judiciária no passado e que, no Brasil, é desempenhada pela polícia e posteriormente repetida no momento da instrução criminal. ${ }^{29} \mathrm{De}$ fato, a pesquisa mostrou que a polícia não se contenta em apenas verificar se há elementos suficientes para que o Ministério Público possa fazer a acusação, mas busca já formar a culpa, ainda que apenas na fase de investigação e o faz, primordialmente, por meio de testemunhos e da confissão do réu.

Seguindo nessa mesma direção, procedemos à análise do tempo gasto no processamento, de maneira a obter indicações sobre a ordem dada a estes procedimentos e o resultado deste ordenamento. Para realizá-la delimitamos alguns marcos temporais: o fato ou o seu registro (t1), a abertura do inquérito (t2), o interrogatório do suspeito (t3) e o encerramento do inquérito (t4), conforme disposto na figura que se segue.

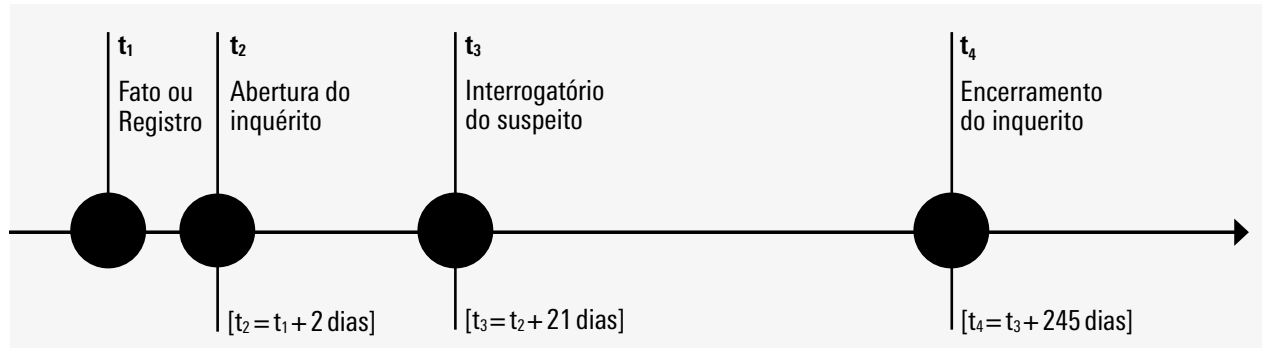

Fonte: Vargas \& Nascimento (2010). 
Em média, dois dias se passam entre o registro da ocorrência e a abertura do inquérito policial. Após o início das investigações, cerca de 21 dias, em média, se passam até que o suspeito do crime seja interrogado e seu depoimento tomado pela polícia. Do interrogatório desse suspeito até o encerramento do inquérito, passam-se, em média, 245 dias.

Isso nos levou a inferir que, nos inquéritos bem-sucedidos, o processo da investigação chega muito rapidamente a um suspeito do crime de homicídio e, em geral, obtém a sua confissão, posteriormente registrada nos autos do interrogatório. Como foi observado desde os primeiros estudos etnográficos realizados sobre o tema no Brasil: primeiro identifica-se o suspeito para depois reconstituir a sua culpa. ${ }^{30}$

A confissão tem servido assim de orientação e de elemento-chave para fazer progredir o processo de formação da culpa. Com base nela obtém-se e se seleciona as provas materiais e é definido quem mais interrogar ou que informação levantar.

Por outro lado, leva-se muito tempo para a reunião dos registros testemunhais e técnicos que corroborem ou que se adaptem à confissão ou mesmo que venham a ganhar força como elementos de prova, independentes desta. Isto porque o resultado da investigação deve ser articulado a princípios e procedimentos definidos nos códigos e transposto por escrito para o corpo dos autos de investigação, de maneira a atender à tradição secular, presente em nossa cultura jurídica e política, de tudo registrar, atestar a veracidade e arquivar em cartórios. Desta tradição decorre que o escrivão acaba assumindo um papel fundamental no processo de elucidação do crime e na própria condução dos inquéritos policiais, ficando a atividade burocrática e cartorial privilegiada em detrimento da atividade investigativa.

\section{DAS PRÁtICAS DE INVESTIGAÇÃO AO INQUÉRITO POLICIAL}

A confissão como principal critério de produção da "verdade real", configura-se no Brasil como uma espécie de tradição ou crença de longa duração que tem legitimado, dentre outras, a prática de tortura em processos investigativos. Este tema, pioneiramente tratado por Roberto Kant de Lima ${ }^{31}$ merece, a meu ver, ser melhor compreendido. Meu esforço nessa direção também segue a indicação para atentar para a transposição das práticas policiais para a lógica reconstruída do relato (Paixão, 1982). ${ }^{32}$

Assim, tem me parecido significativo captar como os "indícios" de provas são construídos e como os relatos escritos e juridicamente orientados vão criando mundo (fatos) e ao mesmo tempo apresentam esses fatos como se fossem propriedade de algo e não produzidos por alguém.

Uma leitura mais detalhada dos relatos do inquérito policial levou-me a discutir a natureza das descrições ali empreendidas e as práticas adotadas 
pela polícia para conferir objetividade e faticidade a essas descrições (Vargas, 2000). Uma delas é tomar distância no reportar da narrativa do outro. E para isso, é empregado o discurso indireto, o uso do conectivo "que", da terceira pessoa, do tempo passado ou de advérbios. Uma menor distância no reportar da narrativa pode também indicar que o descrito foi considerado crível por quem enuncia. Outra prática significativa consiste em reconhecer, interpretar e pinçar, dentro de narrativas singulares, trechos traduzidos para os relatos escritos que buscam apresentar uma descrição do evento compatível com aquela que o crime deve ter. ${ }^{33}$

Mas há ainda aquilo que não aparece no relato e que, no entanto, é decisivo na constituição da faticidade, qual seja, as interpretações policiais sobre ordem e desordem, as categorizações e tipificações que as orientam e que definem as escolhas feitas sobre o que e quem vai ser interrogado ou ouvido, privilegiando certas versões em detrimento de outras. Também estão ausentes do relato os métodos (de trabalho) utilizados para obtê-lo, com destaque para aqueles, como a tortura ou a pressão psicológica, empregados para a obtenção da confissão do indivíduo contra a sua vontade.

É na transposição das práticas de investigação para os relatos juridicamente orientados do inquérito policial, tais como auto de prisão em flagrante delito, auto de qualificação e interrogatório, auto de tomada de depoimento e relatório final que um relato coerente sobre o crime e sua autoria vai sendo construído, constituindo a faticidade do crime, atestada em cartório. E isto é feito por uma autoridade (o delegado) que é responsável, de um lado, pela realização ou condução da investigação na busca da determinação da autoria e da materialidade e, de outro, pelo controle da legalidade dos procedimentos empregados na investigação.

Assim, na transposição das práticas de investigação para os relatos do inquérito policial, os métodos empregados para decidir sobre o que realmente aconteceu e que foram decisivos para constituir "os fatos" muitas vezes desaparecem. Especialmente se ilegais, estes estarão ausentes dos textos, embora tenham sido fundamentais para a constituição daquilo que possa a vir a ser considerado como prova.

Como já ressaltado, a investigação, no modelo brasileiro do inquérito policial, não se restringe ao levantamento de indícios de prova. Se assim fosse, não seria necessária a busca da confissão e muito menos usar da violência física ou psicológica para obtê-la. Bastaria apresentar o que foi apurado ao promotor que decidiria ou não pela acusação. Mas o que a polícia faz, de fato, ao indiciar, é antecipar a formação da culpa, ainda na fase de investigação, buscando constituir provas (e não somente as não repetíveis), mesmo que essas não venham a ter valor de prova reconhecido posteriormente.

Relatos e descrições policiais buscam conferir caráter de prova, mais do que de indícios aos eventos e são elaborados nos autos do inquérito policial, 
muitas vezes sem a atuação da defesa, entranhados aos processos e amplamente utilizados nas fases posteriores de instrução judicial e de sentença. Tudo isso representa uma séria ameaça aos direitos do investigado. Por outro lado, basta a invalidação de um elemento importante para que toda a faticidade se desfigure e meses e não poucas vezes, anos passados da instauração do inquérito, ele seja simplesmente arquivado. Isso pode acarretar, como consequência, a acusação infundada de inocentes, como também permitir que casos de culpabilidade considerada notória escapem das malhas da polícia e da justiça.

Assim, relatos escritos não se prestam apenas a apresentar as versões dos envolvidos devidamente traduzidas para a linguagem jurídica. Ao encadear e ordenar os elementos que reconstituem "o que foi que aconteceu", esses relatos tornam-se decisivos na elaboração da faticidade do crime. Nesse sentido, o inquérito policial desempenha um papel fundamental na permanência da confissão, mesmo contra a vontade do réu, na medida em que permite apresentar a investigação como deveria ser e não como foi efetivamente realizada.

$\mathrm{Na}$ atualidade, o inquérito policial vem perdendo legitimidade e um acalorado debate e várias propostas de reforma ou de extinção desse instrumento vêm sendo aventadas. Há mais de dez anos tramitam no Congresso Nacional propostas de simplificação da investigação criminal sem, entretanto, alcançar nenhum resultado. ${ }^{34}$ Diversos fatores concorrem para a sua permanência. Um deles, particularmente importante, é a crença epistemológica de que se pode atingir e se deve buscar a "verdade real" (este estranho pleonasmo elaborado pela dogmática jurídica brasileira). A simplificação da fase investigatória prejudicaria essa busca.

\section{CONCLUSÃo}

Os textos produzidos na fase policial buscam a elucidação do "fato", "do que aconteceu realmente", "da verdade" e geralmente contêm diferentes pontos de vistas, muitas vezes conflitantes. Mas a "verdade" das partes deve ser abandonada em proveito da "verdade real". Do mesmo modo, os códigos em vigor no Brasil abraçam uma concepção de verdade "a ser descoberta" e não de verdades socialmente produzidas. A ideia de verdades produzidas é negada na dogmática jurídica da busca da "verdade real" e também no famoso bordão do processo penal brasileiro "o que não está nos autos não existe no mundo". Embora este último possa induzir a pensar o contrário, o que nele está implícito é a ideia de que para constar dos autos, a reconstituição da "verdade real" precisa seguir procedimentos formais atestados por escrito por uma autoridade legal. ${ }^{35}$

A polícia, ainda que defenda a crença na possibilidade de obtenção da verdade por meio de procedimentos científicos de investigação, na prática, quando da administração das disputas que demandam a pesquisa da verdade, 
continua a realizar a investigação por meio da confissão e dos testemunhos que os próprios juristas denominam de "prostituta das provas".

Finalmente, parece-me importante ressaltar que a permanência da tortura como critério de produção da verdade não parece constituir uma exceção, um desvio, mas talvez uma crença epistemológica de longa duração. Tal crença não é diferente daquela que almejava alcançar uma verdade quase divina que abriu caminho no passado para o uso legal da tortura, como método de produção de provas. Outra crença epistemológica informou a interpretação de John Luccock, a de que a verdade é intersubjetiva, resultado da troca de pontos de vistas, embora referentes a evidências empíricas produzidas por investigação competente sobre "o que foi que realmente aconteceu".

Artigo recebido para publicação em abril de 2012.

Joana Domingues Vargas é doutora em Sociologia, professora adjunta do Núcleo de Estudos de Políticas Públicas da Universidade Federal do Rio de Janeiro (UFRJ), professora do Programa de Pós-Graduação em Sociologia e Antropologia da mesma instituição e pesquisadora do Conselho Nacional de Desenvolvimento Científico e Tecnológico (CNPq). Atua na área de sociologia da criminalidade e das instituições da segurança pública e da justiça criminal, desenvolvendo pesquisas sobre os seguintes temas: sistema de justiça criminal, justiça juvenil e criminalidade urbana. 


\section{NOTAS}

* Michel Misse, com a generosidade intelectual que lhe é característica, debateu comigo o tema desenvolvido nestas páginas e fez inúmeras sugestões ao texto. Também desfrutei, como tem sido com os meus escritos ao longo dos anos, dos comentários e críticas de Léa Carvalho Rodrigues.

1 A obra de John Luccock Notes on Rio de Janeiro and the Southern parts of Brazil taken during a residence of ten years in that country, from 1808 to 1818 foi publicada em Londres, em 1820. No Brasil, a obra foi intitulada Notas sobre o Rio de Janeiro e partes meridionais do Brasil e publicada pela Martins Editora, em 1942; nova edição ocorreu em 1975. O presente texto baseou-se na obra original e na reedição de 1975.

2 A Intendência Geral de Polícia criada pela corte portuguesa recém-chegada tinha atribuições muito amplas, tal como era próprio à polícia da época, responsável pela boa ordem (Neocleous, 2000). Estas eram relacionadas ao policiamento e à investigação, mas também à administração, abastecimento e iluminação da cidade do Rio de Janeiro. O primeiro intendente a ocupar o cargo, Paulo Fernandes Vianna era desembargador da Relação do Rio de Janeiro, reunia, como era próprio daquele tempo, poderes administrativos e judiciais (Holloway, 1997).

3 Ministro era expressão que designava os magistrados ou juízes letrados.

4 Segundo alguns autores (Parry, 1975), vigia na Inglaterra a tortura extra-processual, "la peine forte et dure" [a pena forte e dura] que pressionava o acusado até a morte, buscando obrigá-lo a aceitar o julgamento. Naquele momento, o julgamento requeria o consentimento do acusado e este poderia optar por dele ficar isento de maneira a preservar o seu nome, bens e a presunção da sua inocência. Langbein (2006:77), entretanto, distingue a tortura para obtenção da confissão de outras formas estatais de infligir dor. Para o autor, esta não se confundiria nem com a pena forte e dura e nem com sanções aflitivas. Embora considere que tais formas de infligir dor tenham aberto o caminho para que se instalasse a tortura judicial. 
5 O uso legal da tortura era previsto apenas para crimes de pena capital. Esta também não era utilizada em mulheres, crianças, velhos, doentes etc. Médicos ou cirurgiões acompanhavam as sessões para atestar o estado de saúde do investigado. Buscava-se limitar o seu uso a casos com alta probabilidade de o acusado ser culpado.

6 Tanto o sistema continental do inquérito quanto o sistema do trial by jury da common-law sucederam aos ordálios (julgamentos baseados em testes e provas em que se manifestaria a intervenção divina) e teriam por origem comum o inquest (Lima, 2009). Entretanto, segundo Langbein (2006), o sistema continental apresentaria, naquele momento, uma evolução não só em relação aos ordálios, quanto à common-law, de origem inglesa. Isto porque, enquanto no sistema continental a decisão é alcançada com a soma quantitativa de provas, na common-law a decisão decorreria do arbítrio do júri. Assim, uma decisão do júri, de pena capital, poderia se dar com base em provas que no sistema continental sequer levariam a justificar o emprego da tortura. A este respeito, ver também Ribeiro (2004: 195).

7 A partir dos séculos XVIII e XIX, tanto o sistema continental quanto o sistema de trial by jury irão sofrer mutações que condicionarão as suas formas atuais. A regra das duas testemunhas e a tortura legal serão abandonadas e várias características do sistema da common-law serão incorporadas à tradição continental, especialmente aquelas voltadas para as garantias do acusado. Diversas reformas darão origem ao sistema adversarial anglo-americano que também incorporará elementos do sistema continental. Permanecerá, entretanto, a característica definidora que os distingue: buscar, no primeiro caso, e não buscar, no segundo, uma verdade imanente.

8 Que o emprego da tortura para a apuração de um evento pudesse levar facilmente ao erro ou ao engano, sendo a sua funcionalidade discutível, era fato amplamente aceito e reconhecido. Até mesmo o manual de inquisidores faz referência a esta questão: "Hombres pusilanimes hay que al primer dolor confiesan hasta delitos que no han cometido; otros valientes y robustos aguantan los mas crueles tormentos" (Eymeric, 1974). 
9 A tese defendida por Langbein, de maneira independente, vai na mesma direção da de Foucault para explicar as mudanças no sistema de punição, tanto em relação ao inexpressivo papel das reformas iluministas, como à emergência de novas formas de castigo. Contudo, a interpretação de Langbein centra-se na mudança dentro do sistema penal e, mais especificamente, em relação à lei da prova. Isso, em uma perspectiva de longa duração. O que, por um lado, diferencia a sua análise da de Foucault e, por outro, a aproxima da de Elias (1996), na medida em que privilegia, em sua análise, como o processo de centralização do Estado foi permitindo uma maior profissionalização e discricionariedade dos agentes do judiciário.

10 O artigo 179 da Constituição de 1824 aboliu "os açoites, a tortura, a marca de ferro quente e todas as mais penas cruéis". Entretanto, o Código criminal de 1830 previa penas de açoites e a submissão a ferro para escravos, só definitivamente abolidas no Código Penal de 1890 (Jesus, 2009: 72).

11 É o que nos sugerem o teor das acusações presentes no Processo e os interrogatórios em que réus foram submetidos à tortura registrada em seguida aos "despachos" justificando o seu uso: "Visto o Decreto de sua Magestade por que hé servido mandar se possão dar tormentos a estes Reos, e vista a prova que rezulta, e forma com qué respondeo o Reo [...] e estar em termos, supposta a gravidade do delicto de ser mettido a tormento, mandão que ao dito Reo se dem dous tratos espertos, se tanto poder tolerar a juizo do cirurgião, a fim de que declare a verdade pelo que respeita a Terceiros" (Azevedo, 1921: 84).

12 Nos autos da devassa consta que o principal "tormento" a que foram submetidos os inconfidentes foi ficarem no "segredo", isto é, presos e incomunicáveis por um decurso de tempo muito maior do que aquele permitido legalmente, dentre outros, devido à confusão decorrente da instalação de duas devassas, uma em Minas e outra no Rio de Janeiro.

13 Apesar das Ordenações Filipinas preverem a morte para uma série enorme de crimes, dentre eles, o furto, elas só era excepcionalmente aplicadas, particularmente nas colônias onde a administração da justiça era bastante autônoma em relação à metrópole (Hespanha, 1994). 
$14 \mathrm{Um}$ caso famoso em que a Justiça valeu-se da tortura para obtenção da confissão é o de Isidoro, um garimpeiro pardo, ex-escravo, que viveu no Distrito Diamantino e, em 1809, foi preso e torturado até a morte por Manuel Ferreira da Câmara Bitencourt e Sá - o intendente Câmara -, para que confessasse como se dava o seu comércio de diamantes. A este respeito, ver Souza, (2004).

15 No primeiro terço do século XIX a população brasileira cresceu rapidamente. Aumentou a imigração de brancos, o número de negros trazidos pela escravidão foi o mais expressivo até então e a população mestiça ganhava cada vez mais visibilidade. Assim, nas cidades brasileiras e no Rio de Janeiro em particular, não se tratava somente da existência de um lupemproletariado, tal como afirmou Charles Boxer (2002), mas também de uma espécie de baixa classe média formada de negros livres, mestiços e brancos (Silva, 2011).

16 Theodor von Leithold e seu sobrinho Ludwig von Rango, assim como muitos outros viajantes, vieram para o Rio de Janeiro alguns anos depois da transferência da Corte portuguesa. Após uma curta permanência de menos de um ano regressaram à Europa, ainda em 1820.

17 Interessante observar que, na tradição anglo-saxã, o reclamante tem um papel primordial na definição da atuação da polícia e o seu testemunho da situação é considerado a melhor evidência do ocorrido (Black,1971).

18 Na classificação de Ramos os "anjinhos" são descritos como "instrumentos de suplício, como o vis-à-pression das colônias francesas e inglesas que prendiam os dedos polegares da vítima em dois anéis que comprimiam gradualmente por intermédio de uma pequena chave ou parafuso. Era um suplício horrível que os senhores usavam quando queriam obter à força a confissão do escravo, incriminado em uma falta" (1949:108-109).

19 Organização de presidiários criada no Rio de Janeiro, no final dos anos 1970, notabilizada depois pela disputa pelo controle do tráfico de drogas na cidade (Misse,1999).

20 Depoimento de Francisco Viriato Correa, o Japonês, a Geraldo Carneiro (1996).

21 Segundo Thompson (1975), na Inglaterra do século XVIII foi feito um enorme esforço para se projetar uma imagem 
da classe dominante como sujeita também ao domínio das leis. Nesse contexto, ganhou legitimidade até mesmo uma lei extremamente cruel e punitiva como a "lei negra".

22 A verdade real no direito brasileiro é um termo utilizado para se distinguir da verdade formal produzida pelas partes que opera no processo civil brasileiro. Porque o processo penal baseia-se na verdade real, os juízes podem mandar incluir nos autos tudo que pode interessar ao processo, de maneira a formar o seu livre convencimento (Lima, 1989: 67).

23 Em pesquisa de vitimização realizada pelo Instituto de Estudos da Religião (Iser), na região metropolitana do Rio de Janeiro, em 1996, mais de $40 \%$ dos entrevistados afirmaram que concordam ou tendem a concordar que a polícia possa se utilizar de recursos ilegais para obter a confissão de suspeitos (CPDOC-FGV/Iser, pesquisa "Lei, justiça e cidadania", 1997). Pesquisa nacional sobre valores e comportamentos realizada em 2008 pela Nova S/B em parceria com o Ibope detectou que um em cada quatro brasileiros acima de 16 anos usaria a tortura para obter informação de um suspeito. Disponível em <http://www.novasb.com.br/noticia/2008/>. Acesso em 30 jan. 2012.

24 Desde 1990, a prisão para a averiguação de crimes hediondos foi legalizada na modalidade de prisão temporária (Vargas, 2000). Sua função permanece a mesma da prisão correcional ou para averiguação que era ilegal, porém largamente utilizada.

25 Ver relatório final da Campanha Nacional Permanente de Combate à Tortura e à Impunidade, Movimento Nacional de Direitos Humanos (2004: 36).

26 Ver relatório final da Campanha Nacional Permanente de Combate à Tortura e à Impunidade, Movimento Nacional de Direitos Humanos (2004: 40).

27 A pesquisa sob a coordenação nacional de Michel Misse resultou em livro (Misse, 2010). Realizada em Brasília, Rio de Janeiro, Porto Alegre, Recife e Belo Horizonte, a investigação teve por objetivo compreender o papel e a função que o inquérito policial assume no processamento de crimes no Brasil.

28 Em Belo Horizonte, optamos por centrar os nossos esforços de pesquisa em uma delegacia especializada na investigação 
de homicídios e também trabalhamos com uma base de dados do Núcleo de Estudos de Segurança Pública (Nesp), da Fundação João Pinheiro, organizada a partir de informações coletadas em 124 processos de homicídios dolosos já baixados e arquivados no Tribunal de Justiça/MG. Trata-se de processos com sentenças já "transitadas em julgado" e cujo fato original se deu entre 1985 e 2003 (Vargas \& Nascimento, 2010).

29 Segundo o direito penal brasileiro, a instrução criminal é a fase do procedimento penal em que são reunidas as provas que irão subsidiar a decisão do juiz. Nela manifestam-se ambas as partes, atendendo ao princípio do contraditório e da ampla defesa.

30 Para ter sucesso, o inquérito começa de trás para frente com a detenção do suspeito (Paixão, 1982; Mingardi,1992). Essa forma de investigação é típica de um sistema inquisitorial em que primeiro presume-se a culpa do investigado para depois buscar-se provas para a sua condenação (Lima, 1989).

31 Para Roberto Kant de Lima, as práticas policiais atuais no Brasil são típicas de sociedades hierárquicas, tradicionalmente marcadas por seu caráter inquisitorial. Essa tradição teria origem do Tribunal do Santo Ofício Português que buscava a constante autoacusação do réu e empregava a tortura para extrair a sua confissão (Lima,1999: 17) .

32 Segundo Antônio Luiz Paixão, a lógica em uso dos policiais é mais informada por ideologias e estereótipos formulados organizacionalmente (tipificações profissionais) do que por categorias legais. É ela que orienta a ação dos policiais em suas atividades rotineiras (Paixão, 1982: 64).

33 Não é prerrogativa da polícia lançar mão de relatos e de descrições para a constituição da faticidade, do que foi que aconteceu, em seu campo de atuação. A antropologia e a sociologia interpretativas, particularmente a etnometodologia, chamaram a atenção para a importância dessa prática na produção de conhecimento nas suas áreas.

34 Destaca-se o PL 4.209/2001 que propôs modificações no texto original do Código do Processo Penal relativo à investigação criminal. Este foi elaborado por uma comissão de juristas que propuseram retirar da investigação o seu caráter cartorial e burocrático, visando a sua simplificação. 
35 A necessidade de certificação por documentos escritos já era central na Europa moderna e em suas colônias e constituiu o que foi denominado de "civilização do papel selado" (Hespanha,1994). Ancorada na atestação da legalidade dos procedimentos, sua centralidade permanece em países influenciados por essa tradição.

\section{llustrações}

1. Gravura representando a aplicação dos "anjinhos", reproduzida a partir da Constitutio Criminalis Theresiana (Lei de processo criminal na Áustria em 1769) em formato digital. Disponível em <http://archive.org/stream/ConstitutioCriminalisTheresiana1768/Constitutio_Criminalis_Theresiana-1768-complete\#page/n366/mode/1up >. Acesso em 3 nov. 2011.

2. Esmagadores de mãos: uma das peças que seriam levadas a leilão em Paris em 3 abril de 2012. O leilão de 350 instrumentos de tortura pertencentes à coleção de Fernand Meyssonnier, carrasco oficial na Argélia, foi suspenso após protesto de organizações de direitos humanos (Le Monde, 30 de março de 2012). Disponível em <http://www.lemonde. $\mathrm{fr} /$ societe/article/2012/03/30/la-vente-aux-encheres-d-instruments-de-torture-est-suspendue_1678544_3224.html>. Acesso em 5 abr. 2012.

3. Réplica em madeira e ferro de esmaga-polegares (a foto foi feita pela autora no Palacio de la Inquisición, Museo Histórico de Cartagena de Indias, Colômbia).

\section{REFERÊNCIAS BIBLIOGRÁFICAS}

Cardoso, Patrícia Domingos. D. João de Almeida Portugal e a revisão do Processo dos Távoras: conflitos intrigas e linguagens políticas em Portugal nos finais do Antigo Regime (c. 1777-1802). Tese de doutorado. PPH/Universidade Federal Fluminense, 2011.

Azevedo, Pedro (prefaciado e anotado por). O processo dos Távoras. Lisboa: Biblioteca Nacional, 1921. Disponível em <http://www.archive.org/stream/oprocessodostv00tv\#page/ n3/mode/2up>. Acesso em 21 mar. 2012. 
Bethencourt, Francisco. História das Inquisições: Portugal, Espanha e Itália, séculos XV-XIX. São Paulo: Companhia das Letras, 2000.

Black, Donald. The social organization of arrest. Stanford Law Review, 1971, 23/6, p. 1087-1111.

Boxer, Charles. O império marítimo português, 1415-1825. São Paulo: Companhia das Letras, 2002.

Bretas, Marcos L. A polícia carioca no Império. Estudos Históricos, 1998, 12/22, p. 219-234.

Elias, Norbert. O processo civilizador: formação do Estado $e$ civilização. Rio de Janeiro: Jorge Zahar, 1996 (vol. 2).

Eymeric, Nicolau. Manual de inquisidores. Barcelona: Editorial Fontamara SA, 1982.

Foucault, Michel. Vigiar e punir: nascimento da prisão. Petrópolis: Vozes, 1988.

Garfinkel, Harold. Studies in ethnometodology. New Jersey: Prentice Hall, 1967.

Hespanha, Antônio Manuel. As vésperas do Leviathan: instituições e poder político (Portugal, séc. XVIII). Coimbra: Almedina, 1994.

Holloway, Tomas H. Polícia no Rio de Janeiro: repressão e resistência numa cidade do século XIX. Rio de Janeiro: Ed. FGV, 1997. Instituto Carioca de Criminologia. Depoimento de Francisco Viriato Correa, o Japonês, a Geraldo Carneiro. Discursos Sediciosos: Crime, Direito, Sociedade, 1996, 1, p. 13-18.

Jesus, Maria Gorete Marques de. O crime de tortura e a Justiça Criminal. Dissertação de Mestrado. FFLCH/ Universidade de São Paulo, 2009.

Langbein, John H. Torture and the law of proof: Europe and England in the Ancien Régime. Chicago: The University of Chicago Press, 2006.

Leite, Ilka Boaventura. Antropologia da viagem: escravos e libertos em Minas Gerais do século XIX . Belo Horizonte: Ed. UFMG, 1996.

Leithold, Theodor von \& Rango, Ludwig von. O Rio de Janeiro visto por dois prussianos em 1819. São Paulo: Companhia Editora Nacional, 1966. Disponível em <http://www.brasiliana. 
com.br/obras/o-rio-de-janeiro-visto-por-dois-prussianos-em-1819/>. Acesso em 16 jan. 2012.

Lima, Lana Lage da Gama. O tribunal do Santo Ofício da Inquisição: o suspeito é o culpado. Revista de Sociologia e Política, 1999, 13, p. 17-21.

Lima, Roberto Kant. Cultura jurídica e práticas policiais: a tradição inquisitorial. Revista Brasileira de Ciências Sociais, $1989,4 / 10$, p. $65-84$.

A polícia da cidade do Rio de Janeiro: seus dilemas e paradoxos. Rio de Janeiro: Polícia Militar do Rio de Janeiro, 1994.

. Polícia, Justiça e sociedade no Brasil: uma abordagem comparativa dos modelos de administração de conflitos no espaço público. Revista de Sociologia e Política, 1999, 13, p. 23-38.

Direitos civis e direitos humanos: uma tradição judiciária pré-republicana. São Paulo em Perspectiva, 2004, 18/1, p. 49-59.

. Ensaios de Antropologia e de Direito: acesso à justiça e processos institucionais de administração de conflitos e produção da verdade jurídica em uma perspectiva comparada. Rio de Janeiro: Lúmen Júris, 2008.

Sensibilidades jurídicas, saber e poder: bases culturais de alguns aspectos do Direito brasileiro em uma perspectiva comparada. Anuário Antropológico, 2010, 2, p. 25-51.

Luccock, John. Notes on Rio de Janeiro and the southern parts of Brazil taken during a residence of ten years in that country, from 1808 to 1818. Londres: Samuel Leigh, 1820.

. Notas sobre o Rio de Janeiro e partes meridionais do Brasil. Belo Horizonte/São Paulo: Itatiaia/Edusp, 1975.

Mingardi, Guaracy. Tiras, gansos e trutas: cotidiano e reforma na polícia civil. São Paulo: Scritta, 1992.

Misse, Michel. Malandros, marginais e vagabundos. Tese de Doutorado. Instituto Universitário de Pesquisas do Rio de Janeiro, 1999.

_____ (org.). O inquérito policial no Brasil: uma pesquisa empírica. Rio de Janeiro: Booklink/Fenapef/Necvu, 2010.

Neocleous, Mark. The fabrication of social order: a critical theory of police power. Londres: Pluto Press, 2000. 
Paixão, Antônio Luiz. A organização policial numa área metropolitana. Dados, 1982, 25/1, p. 63-85.

Crime, controle social e consolidação da democracia: as metáforas da cidadania. In: O’Donnell, Guillermo \& Reis, Fábio W. (orgs.). A democracia no Brasil: dilemas e perspectivas. São Paulo: Vértice, 1988, p. 168-199.

et al. Métodos e acidentes de trabalho: violência, legalidade e polícia. Análise \& Conjuntura, 1992, 7/2-3, p. 76-91. Parry Leonard. The history of torture in England. Montclair, NJ: Patterson Smith, 1975.

Pinheiro, Paulo Sérgio. Violência do Estado e classes populares. Dados, 1979, 22, p. 5-24.

Ramos, Arthur. A aculturação negra no Brasil. São Paulo: Companhia Editora Nacional, 1942.

Ribeiro, Renato Janine. Ao leitor sem medo: Hobbes escrevendo contra o seu tempo. Belo Horizonte: Ed. UFMG, 2004.

Silva, Alberto da Costa e. População e sociedade. In:

(org.). Crise colonial e Independência (1808-1830). Rio de Janeiro: Objetiva, 2011 p. 35-74. (vol.1)

Schwarcz, Lília Moritz. Cultura. In: Silva, Alberto da Costa e (org.). Crise colonial e Independência (1808-1830). Rio de Janeiro: Objetiva, 2011, p. 205-247. (vol. 1)

Sinhoretto, Jacqueline. A Justiça perto do povo: reforma e gestão de conflitos. São Paulo: Alameda, 2011.

Souza, Laura de Mello e. Desclassificados do ouro: a pobreza mineira no século XVIII. São Paulo: Paz e Terra, 2004.

Thompson, Edward P. Whigs and hunters: the origin of the Black Act. Londres: Allen Lane, 1975.

Varnhagen, Francisco Adolpho de. História geral do Brasil. Tomo V. São Paulo: Melhoramentos, 1962, p. 221-223.

Vargas, Joana D. Crimes sexuais e sistema de justiça. São Paulo: IBCCrim, 2000.

Estupro: que Justiça? Fluxo do funcionamento e análise do tempo da justiça criminal para o crime de estupro. Tese de doutorado. Instituto Universitário de Pesquisas do Rio de Janeiro, 2004. 
EM BUSCA DA "VERDADE REAL": TORTURA E CONFISSÃO NO BRASIL ONTEM E HOJE

264

. Análise comparada do fluxo do sistema de justiça para o crime de estupro. Dados, 2007, 50, p. 671-697.

\& Nascimento, Luís Felipe Z. Uma abordagem empírica do inquérito policial: o caso de Belo Horizonte. In: Misse, Michel (org.). O inquérito policial no Brasil: uma pesquisa empírica. Rio de Janeiro: Booklink/Fenapef/Necvu, 2010, p. 102-190. 


\section{Palavras-chave: Resumo:}

Tortura; Polícia; Confissão; Inquérito policial; Brasil.

Keywords:

Torture; Police; Confession; Inquest report; Brazil.
Meu ponto de partida, neste ensaio, são as diferenças nas formas de investigação no Brasil e na Inglaterra analisadas com base em um relato de um viajante estrangeiro do século XIX contendo a visão do autor sobre a administração da justiça na cidade do Rio de Janeiro informada pela experiência de um furto. Nele procuro mostrar a permanência e persistência de uma crença epistemológica sobre o valor da confissão e da tortura que ainda informam as práticas de produção da verdade no Brasil contemporâneo. Uma das razões desta permanência é a investigação poder ser apresentada, nos relatos juridicamente orientados, como ela deveria ser e não como ela é realizada efetivamente. Este achado tem implicação para o debate atual sobre a necessidade de simplificação da investigação criminal no Brasil.

\section{Abstract:}

The starting point of this essay are the differences in the forms of inquiry in Brazil and England based on a report of a foreign traveler of the nineteenth century containing the author's view on the administration of justice in the city of Rio de Janeiro informed by his experience of a theft. I point to the remarkable permanence and persistence of an epistemological belief in the value of confession and torture to obtain evidence, which still informs the production practices of truth in contemporary Brazil. One of the reasons of this permanence is that in the juridical records, investigation can be presented as it should have been carried out and not as it was actually done. 